J. Lake Sci. (湖泊科学), 2015, 27 (6): 1079-1086

DOI 10. 18307/2015. 0612

(C) 2015 by Journal of Lake Sciences

\title{
福建敖江流域水域生态系统健康评估"
}

张玉珍 $^{1,2}$, 黄文丹 ${ }^{1,2}$, 王智苑 ${ }^{3,4}$, 鲍秋萍 ${ }^{1,2}$, 姜炳棋 ${ }^{1,2}$

( 1 : 福建省环境科学研究院, 福州 350013 )

( 2 : 福建省环境工程重点实验室, 福州 350013)

(3:福州市农业局,福州 350007)

( 4 : 福州市农田建设与土壤肥料技术站,福州 350007 )

摘 要: 以敖江流域为研究区, 通过采集底栖动物、鱼类等样品, 结合监测数据分析流域水域生态系统健康状况, 并采用 指标体系评估方法对水域生态系统进行评估. 结果表明: 敖江流域水质总体良好, 但山仔水库总氮、总磷浓度长期超标, 水体存在富营养化和藻类水华暴发生态环境问题; 底栖动物种类呈现支流多于干流、河流多于水库的规律; 鱼类种类上、 中、下游各科物种组成差异不显著, 鱼类区系特点具有较明显的热带、亚热带区系特点; 流域上游、中游水域生态健康良 好,下游水域生态健康一般.

关键词: 敖江流域;山仔水库;水域生态系统;健康评估

\section{Evaluation of aquatic ecosystem health in Aojiang Basin, Fujian Province}

\author{
ZHANG Yuzhen ${ }^{1,2}$, HUANG Wendan ${ }^{1,2}$, WANG Zhiyuan $^{3,4}$, BAO Qiuping ${ }^{1,2}$ \& JIANG Bingqi ${ }^{1,2}$ \\ (1: Fujian Provincial Academy of Environmental Science, Fuzhou 350013, P. R. China) \\ (2: Fujian Key Laboratory of Environmental Engineering, Fuzhou 350013, P. R. China) \\ (3: Fuzhou Agricultural Bureau, Fuzhou 350007, P. R. China) \\ (4: Fuzhou Farmland Construction and Soil and Fertilizer Technology Station, Fuzhou 350007, P. R. China)
}

\begin{abstract}
According to the suvery on benthic animal and fish samples, and combining with monitoring data, we analyzed the health condition of aquatic ecosystem, and made evaluation with an index in Aojiang Basin. The results showed that the water quality was generally good in Aojiang Basin, but total nitrogen and total phosphorus concentration of Shanzi Reservoir exceeded standard for a long term which led to ecological environment problems, such as eutrophication and algae outbreak. Species numbers of benthic animals presented in the tributaries were greater than that in the river, with smallest species number in reservoir. The fish composition in the upstream, midstream and downstream was not of significant difference, exhibiting a tropical and subtropical floristic characteristics. The health condition of aquatic ecosystem in both upstream and midstream was good, while that in downstream was moderate.
\end{abstract}

Keywords: Aojiang Basin; Shanzi Reservoir; aquatic ecosystems; health evaluation

生态系统健康是近年来国内外研究热点, 受到越来越多的重视, 研究者们纷纷采取措施对流域进行生 态系统健康评估 ${ }^{[14]}$. 从 1980s 开始, 国外学者就已开展流域生态系统健康评估研究, 集中在流域生态健康评 价模型和指标体系等方面 ${ }^{[5-8]}$. 国内开展流域生态健康评估研究起步较晚, 从 1990s 开始, 侧重于生态系统健 康相关概念与评估理论方法研究 ${ }^{[9-11]}$. 随着人口增长, 工农业、水利工程的发展, 敖江流域出现了水生态环境 问题, 部分水域水体被严重污染, 发生藻类水华现象 ${ }^{[12]}$, 部分河段自然生境改变, 由急流、激流转为缓流或静 水区, 河流水体净化功能弱化, 底栖动物、鱼类等生物的生境片断化; 部分河段水体受工业点源污染, 浊度超 标, 胁迫水生生物, 已严重威胁河道内水生生物的多样性 ${ }^{[13]}$. 敖江中游的山仔水库是福州市级饮用水源地,

* 福建省环保科技计划项目(2013R011) 资助. 2014-09-16 收稿;2015-02-10 收修改稿. 张玉珍( 1964 ), 女, 博 士, 教授级高级工程师; E-mail:zyz9893@163.com. 
氮、磷营养盐浓度常年超标, 在亚热带气候背景下, 夏季常暴发蓝藻水华, 存在供水安全隐患 ${ }^{[14]}$. 因此, 对敖 江流域的水域生态系统健康进行评估, 以期为全面了解敖江流域生态系统健康提供基础, 为敖江流域生态 环境保护和治理提供科学依据.

\section{1 研究区概况}

敖江是福建省 “八大水系”之一, 是闽东三条独流人海的主要河流之一, 发源于宁德市古田县鹑峰山脉 东, 主流流经宁德市古田县, 福州市的闽侯县、闽清县、罗源县、晋安区、连江县, 最后于连江县东岱镇大涂村 处注人东海, 流域面积 $2655 \mathrm{~km}^{2}$, 占全省面积的 $2.16 \%$. 敖江流域水资源丰富, 多年平均径流深为 $1027 \mathrm{~mm}$, 平均流量为 $87.7 \mathrm{~m}^{3} / \mathrm{s}$, 径流量为 $30.5 \times 10^{8} \mathrm{~m}^{3}$, 多年全年月均径流量达 $58.3 \mathrm{~m}^{3} / \mathrm{s}^{[15]}$. 敖江的山仔一塘坂水源 地是福州市、连江县水厂的水源.

以自然集水区为基础, 同时参考行政区边界, 对流域水域进行评估水系划分, 划定 3 个评估水系: 上游、 中游和下游水系, 其中上游和下游水系无大型水库, 定为河流型水系, 中游因有山仔水库, 定为湖库型水系. 敖江流域上游水系涉及支流有徐州溪、紫峰溪、黄埔溪、文山岗溪、险桥溪、油溪; 中游水系涉及支流有佳湖 溪、日溪、斌溪、华林溪、赤石溪，下游水系涉及支流有牛溪、桂湖溪、梅洋溪、财溪(图 1).

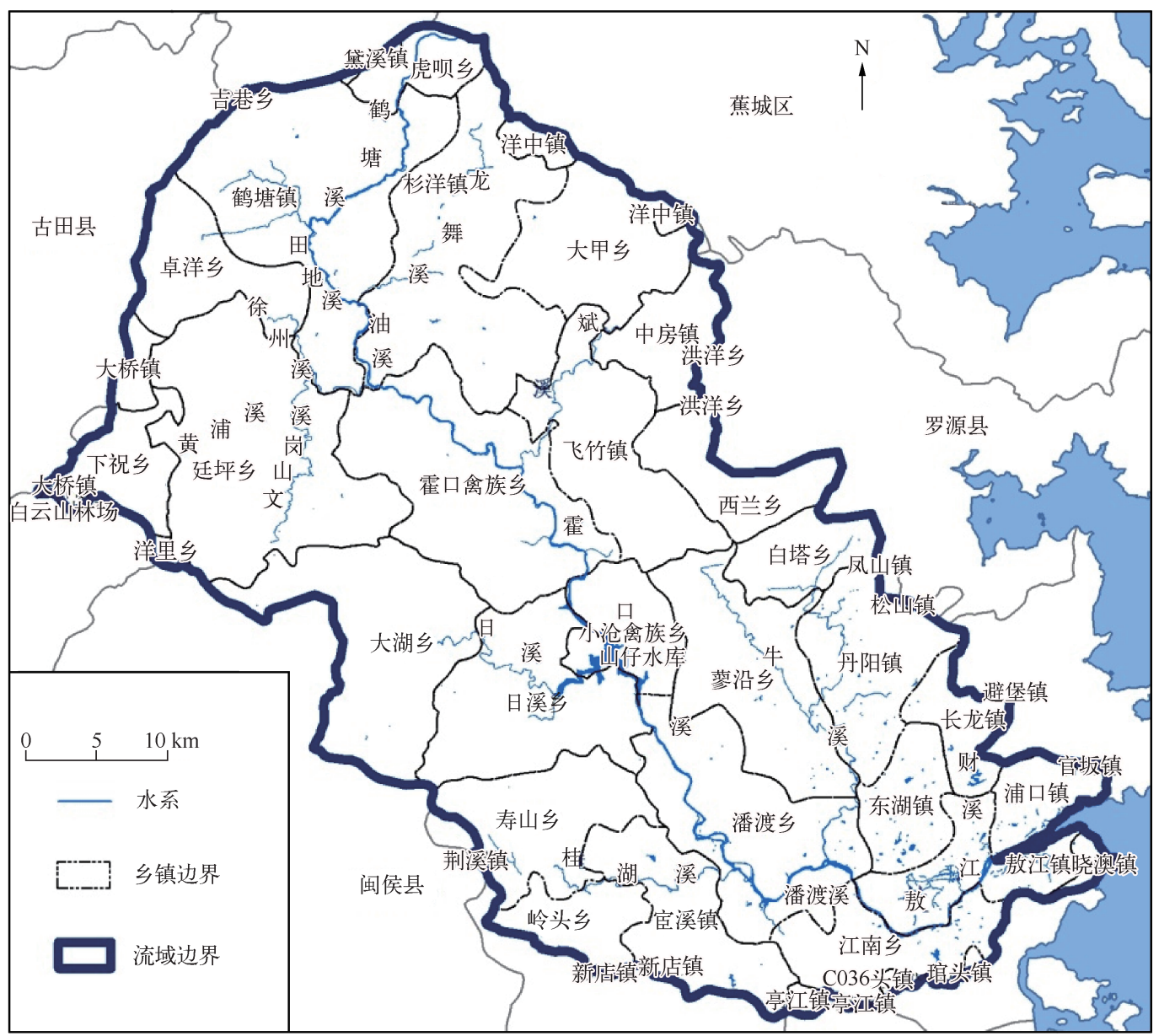

图 1 敖江流域地理位置

Fig. 1 The geographic location of Aojiang Basin 


\section{2 材料与方法}

\section{1 水质监测断面布设}

利用福建省环境保护部门历年在敖江流域 布设的各级监控断面 (表 1 ) 的水质数据, 及 $2005-2013$ 年山仔水库总氮 ( TN) 、总磷 ( TP) 浓 度年均监测等数据, 分析敖江流域河流和水库 水质状况.

\section{2 底栖动物、鱼类采样断面布设}

于 2013 年夏季 (7-8 月)采集敖江流域的 底栖动物和鱼类样品, 共布设 9 个采样断面, 9 个断面均采集底栖动物样品, 在霍口下游等 4 个 断面采集鱼类样品,各断面基本情况见表 2.
表 1 敖江流域河流型水质监测断面

Tab. 1 Water quality monitoring section of river type in Aojiang Basin

\begin{tabular}{cccc}
\hline 区县 & 断面名称 & 所在河流 & 断面级别 \\
\hline 古田县 & 双口渡 & 干流 & 省控、交界 \\
罗源县 & 霍口 & 干流 & 省控 \\
连江县 & 梧桐溪 & 干流 & 省控 \\
连江县 & 塘坂水库 & 干流 & 省控 \\
连江县 & 贵安 & 干流 & 省控 \\
连江县 & 长汀 & 干流 & 省控 \\
连江县 & 荷山渡口 & 干流 & 国控、人海河口 \\
\hline
\end{tabular}

表 2 敖江流域底栖动物、鱼类采样断面基本情况

Tab. 2 Benthic animals and fish sampling section in Aojiang Basin

\begin{tabular}{ccccccc}
\hline 编号 & 点位 & 所在河流 & 底质类型 & 河宽 $/ \mathrm{m}$ & 水深 $/ \mathrm{m}$ & 样品类型 \\
\hline 1 & 罗溪 & 支流 & 砾石 & $3 \sim 4$ & $0.2 \sim 0.5$ & 底栖动物 \\
2 & 霍口中上游 & 干流 & 基岩、卵石 & $50 \sim 60$ & $0.5 \sim 1.0$ & 底栖动物 \\
3 & 霍口下游 & 干流 & 细沙质 & $50 \sim 60$ & $0.5 \sim 2.0$ & 底栖动物、鱼类 \\
4 & 傍溪 & 支流 & 漂石、粗沙质、水生植物 & $3 \sim 4$ & $0.2 \sim 0.4$ & 底栖动物 \\
5 & 山仔水库(日溪人库处) & 干流水库 & 淤泥 & $20 \sim 30$ & 10 & 底栖动物 \\
6 & 山仔水库 & 干流水库 & 淤泥 & - & 10 & 底栖动物、鱼类 \\
7 & 敖江干流 (近塘坂水库) & 干流 & 我鸟卵石、少量淤泥、水草 & $50 \sim 60$ & $0.5 \sim 2.0$ & 底栖动物 \\
8 & 潘渡溪 & 干流 & 我卯石、水藻、水草 & $50 \sim 60$ & $1 \sim 3$ & 底栖动物、鱼类 \\
9 & 下游浦口 & 干流 & 淤泥 & $50 \sim 60$ & 10 & 底栖动物、鱼类 \\
\hline
\end{tabular}

\section{3 采样和分析方法}

2.3.1 底栖动物采样和分析方法 河流底栖动物采样工具为 D-型网. 河口及湖库水深处底栖动物采样用改 良式彼得森采泥器, 适合采集淤泥及较软的底泥, 开口面积为 $1 / 16 \mathrm{~m}^{2}$. 底栖动物采集标本后, 送至福建师范 大学生命科学学院进行分析,采用镜检分析法,对照底栖动物图谱进行分类.

2.3 .2 鱼类采样和分析方法 鱼类采样方法为渔获物调查法, 即从当地渔民渔获物中获取相应样品. 鱼类样 品采集后立即送至福建师范大学生命科学学院进行鉴定. 室内鱼类物种鉴定包括基本的鱼类形态测定, 必 要时解剖观察, 根据《中国鱼类系统检索》 ${ }^{[16]}$ 进行分类.

\section{4 评估方法}

参考环境保护部《流域生态健康评估技术指南》 ${ }^{[17]}$, 结合敖江流域实际情况, 确定 8 项水域生态系统健 康评估指标, 其中生态结构 3 项、水生生物 3 项、生态压力 2 项, 具体评估指标类型、权重和标准分级见表 3.

\section{3 结果与讨论}

\section{1 流域水质情况}

3.1 .1 河流水质情况 2005-2013 年敖江流域水质达标情况 (表 4) 可知,敖江流域水质呈逐步改善趋势. 2013 年敖江流域水质总体良好,6 个国、省控断面水域功能达标率和 I III类水质比例均为 $100 \%$, 较 2005 年均提高了 $16.7 \%$. 敖江流域水质浊度达标率有所提高, 2010 年福州段的霍口断面、古田县双口渡断面的浊 度达标率分别为 $88.08 \%$ 和 $88.17 \%$, 均实现了省政府下达的整治目标, 但福州段兰水溪和花园溪断面浊度 达标率不高,存在超标. 
表 3 敖江流域水域生态健康评估指标体系和标准分级

Tab. 3 Health evaluation index system and standard classification of aquatic ecosystem in Aojiang Basin

\begin{tabular}{|c|c|c|c|c|c|c|c|c|c|}
\hline \multirow[b]{2}{*}{ 指标类型 } & \multirow{2}{*}{\multicolumn{2}{|c|}{ 评估指标 }} & \multicolumn{2}{|c|}{ 指标权重 } & \multicolumn{5}{|c|}{ 标准分级及赋分 } \\
\hline & & & 河流型 & 湖库型 & $\begin{array}{l}\text { 优秀 } \\
\geqslant 80\end{array}$ & $\begin{array}{c}\text { 良好 } \\
60 \sim 80\end{array}$ & $\begin{array}{c}\text { 一般 } \\
40 \sim 60\end{array}$ & $\begin{array}{c}\text { 较差 } \\
20 \sim 40\end{array}$ & $\begin{array}{l}\text { 差 } \\
<20\end{array}$ \\
\hline \multirow[t]{3}{*}{ 生态结构 } & \multirow{2}{*}{\multicolumn{2}{|c|}{$\begin{array}{l}\text { 水质状况指数 } / \% \\
\text { 枯水期径流量占同期年均 } \\
\text { 径流量比例 } / \%\end{array}$}} & 0.16 & 0.16 & $\geqslant 80$ & $60 \sim 80$ & $40 \sim 60$ & $20 \sim 40$ & $<20$ \\
\hline & & & 0.12 & 0.12 & $\geqslant 1.3$ & $1.1 \sim 1.3$ & $0.9 \sim 1.1$ & $0.7 \sim 0.9$ & $<0.7$ \\
\hline & \multicolumn{2}{|c|}{ 河道连通性 } & 0.12 & 0.12 & $<3$ & $3 \sim 8$ & $8 \sim 10$ & $10 \sim 20$ & $\geqslant 20$ \\
\hline \multirow[t]{3}{*}{ 水生生物 } & \multicolumn{2}{|c|}{$\begin{array}{l}\text { 大型底栖动物多样性综合 } \\
\text { 指数 }\end{array}$} & 0.12 & 0.12 & $0.8 \sim 1.0$ & $0.6 \sim 0.8$ & $0.4 \sim 0.6$ & $0.2 \sim 0.4$ & $0 \sim 0.2$ \\
\hline & \multicolumn{2}{|c|}{ 鱼类物种多样性综合指数 } & 0.12 & 0.12 & $0.8 \sim 1.0$ & $0.6 \sim 0.8$ & $0.4 \sim 0.6$ & $0.2 \sim 0.4$ & $0 \sim 0.2$ \\
\hline & \multicolumn{2}{|c|}{$\begin{array}{l}\text { 特有性或指示性物种保 } \\
\text { 持率/\% }\end{array}$} & 0.06 & 0.06 & 大量增加 & 稍有增加 & 无变化 & 稍有减少 & 大量减少 \\
\hline \multirow[t]{5}{*}{ 生态压力 } & \multicolumn{2}{|c|}{ 水资源开发利用强度/\% } & 0.15 & 0.15 & $<20$ & $20 \sim 35$ & $35 \sim 45$ & $45 \sim 60$ & $\geqslant 60$ \\
\hline & $\begin{array}{l}\text { 水生生境 } \\
\text { 干扰指数 }\end{array}$ & 挖沙 & 0.06 & 0.024 & 无 & 极少 & 部分区域可见 & 常见 & 严重 \\
\hline & & $\begin{array}{l}\text { 航运交通或 } \\
\text { 涉水旅游 }\end{array}$ & 0.06 & 0.024 & 无 & 极少 & 部分区域可见 & 常见 & 严重 \\
\hline & & 网箱养殖 & 0 & 0.072 & 无 & 极少 & 部分区域可见 & 常见 & 严重 \\
\hline & & $\begin{array}{l}\text { 外来物种种 } \\
\text { 类、数量、比例 }\end{array}$ & 0.03 & 0.03 & 大量减少 & 稍有减少 & 无变化 & 稍有增加 & 大量增加 \\
\hline
\end{tabular}

表 4 2005-2013 年敖江流域水质达标情况

Tab. 4 Water quality standards level of Aojiang Basin during 2005-2013

\begin{tabular}{ccccc}
\hline 年份 & 水域功能达标率 $/ \%$ & $\mathrm{I} \sim$ III类水质比例 $/ \%$ & 交界面达标率/\% & 超标断面 (超标指标) \\
\hline 2005 & 83.3 & 83.3 & 91.7 & - \\
2006 & 86.1 & 86.1 & 100 & 连江贵安、荷山渡口(氨氮、总磷) \\
2007 & 100 & 100 & 100 & - \\
2008 & 97.2 & 97.2 & 100 & 连江长汀(生化需氧量) \\
2009 & 100 & 100 & 100 & - \\
2010 & 100 & 100 & 100 & - \\
2011 & 100 & 100 & 100 & - \\
2012 & 100 & 100 & 100 & - \\
2013 & 100 & 100 & 100 & - \\
\hline
\end{tabular}

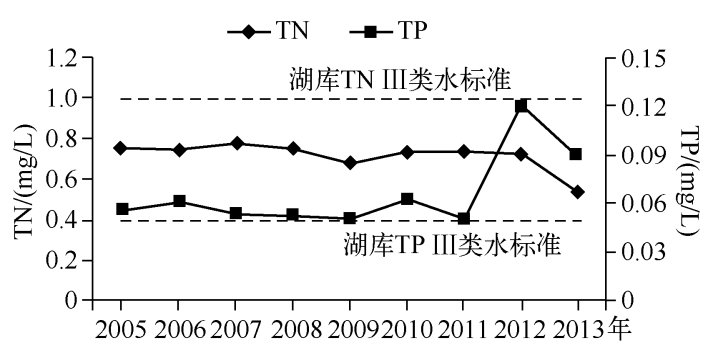

图 $22005-2013$ 年山仔水库水体 $\mathrm{TN}$ 和 $\mathrm{TP}$ 浓度变化

Fig. 2 Concentration changes of total nitrogen and total phosphorus in Shanzi Reservior during 2005-2013
3.1 .2 水库水质情况 根据敖江流域山仔库区历 年丰、平、枯水期监测数据,计算得到 2005-2013 年水体 TN 和 TP 年均浓度 (图 2), 表明 20052013 年山仔水库水体中 TN 和 TP 浓度处于相对 稳定状态, $\mathrm{TN}$ 年均浓度为 $0.54 \sim 0.78 \mathrm{mg} / \mathrm{L}$, 未 超过湖库 III 类水标准 ( $1 \mathrm{mg} / \mathrm{L})$, 而 TP 年均浓度 为 $0.05 \sim 0.12 \mathrm{mg} / \mathrm{L}$, 超过湖库 III 类水标准 $(0.05 \mathrm{mg} / \mathrm{L})$, 主要原因是山仔水库建库之初未 进行底部清淤, 同时又有外部污染源汇人导致其 建库蓄水后水体中氮、磷浓度偏高, 水质连续多年 均未能达标. 由于水库水体中的可溶性氮、磷浓度 较高, 水体呈富营养状态, 促进水生藻类的大量生 
长繁殖, 暴发蓝藻水华. 翁笑艳等 ${ }^{[18]}$ 的研究表明,2010 年 3 月开始山仔水库出现少量蓝藻水华, 水华现象一 直持续到 9 月份. 张玉珍等 ${ }^{[19]}$ 研究发现, 山仔水库夏季水温一般在 $25^{\circ} \mathrm{C}$ 以上, 并持续到 10 月份, 水体透明度 为全年最低, 均低于 $1 \mathrm{~m}$, 水体中浮游植物生物量达到全年最高, 细胞密度在 $10^{7} \sim 10^{8} \mathrm{cell} / \mathrm{s} / \mathrm{L}$ 之间, 且其中蓝 藻密度约占总密度的 $90 \%$ 以上. 山仔水库 TP 浓度 2012 年最高, 这可能受到 2012 年 3-4 月强降雨的影响, 外源输人量较大, 导致 TP 浓度偏高.

\section{2 水生生境特征分析}

3.2 .1 底栖动物群落分析 敖江流域底栖动物组成情况 (表 5) 可知, 敖江流域底栖动物种类呈现支流多于 干流、河流多于水库的规律. 敖江流域上游的罗溪, 中游的霍口下游、傍溪和山仔水库断面均出现颤蚓科, 而 颤蚓科具有耐有机污染和缺氧的特性, 是良好的有机污染指示物种, 由此可见, 这 4 个断面受到不同程度的 有机污染. 敖江流域中游的傍溪断面出现大量的蜉蝣目、毛翅目、襀翅目敏感物种, 说明其自然生境总体保 持较为完整. 敖江流域下游的潘渡溪断面, 种类数为全流域最多, 底栖物种丰富, 主要是受到生境如水深、河床 底质组成等显著影响, 卵石河床是该断面底栖动物种类多的主要原因之一. 根据调查, 敖江流域底栖动物的平均密 度约为 $121 \mathrm{ind} . / \mathrm{m}^{2}$, 中游的傍溪和下游的潘渡溪断面底栖动物密度较高, 分别达到 529 和 $277 \mathrm{ind} . / \mathrm{m}^{2}$, 而中 游的山仔水库、日溪和霍口下游断面底栖动物的密度明显较低, 分别为 $20 、 16$ 和 $14 \mathrm{ind} . / \mathrm{m}^{2}$. 研究发现, 河流 水体中底栖动物的优势种主要有蚋幼虫 (Simulium sp.)、四节蜉幼虫 (Baetidae)、尖头杆吻虫 (Stylaria fossularis) 和多足摇蚊幼虫 (Polypedilum sp. ) 等, 约占总密度的 $57.1 \%$, 集中分布在中游的傍溪和下游的潘渡溪 断面; 库区段底栖动物的优势种主要有多足摇蚊幼虫、长跗摇蚊幼虫 (Tanytarsus sp.) 和多突癞皮虫 (Slavina appendiculata) 等, 约占总密度的 $77.6 \%$; 河口段底栖动物的优势种主要有谭氏泥蟹( Ilyrplax deschampsi)、弧 边招潮蟹 (Uca arcuata) 和夹杂带丝蚂(Lumbriculus variegatus) 等,约占总密度的 $87.7 \%$.

表 5 敖江流域底栖动物物种组成

Tab. 5 The species of benthic animal in Aojiang Basin

\begin{tabular}{|c|c|c|}
\hline 断面 & 类型 & 密度 $/\left(\right.$ ind. $\left./ \mathrm{m}^{2}\right)$ \\
\hline 罗溪 & $\begin{array}{l}\text { 颤蚓科、仙女虫科、石蛭科、椎实螺科、嶰螺科、扁卷螺科、蚬科、长足摇蚊亚科、腺状 } \\
\text { 介虫科 }\end{array}$ & 27 \\
\hline 霍口中上游 & 仙女虫科、黑螺科、蚬科、摇蚊亚科、细蜉科、蜉蝣科、花划蝽科 & 34 \\
\hline 霍口下游 & 颤蚓科、椎实螺科、嶰螺科、蚬科、蟌科、细蜉科、石蝇科、蚋科、花划蝽科 & 14 \\
\hline 傍溪 & $\begin{array}{l}\text { 浴虫纲、㗜蚓科、带丝蚓科、仙女虫科、石蛭科、扁蛭科、蚬科、摇蚊亚科、长足摇蚊亚 } \\
\text { 科、直突摇蚊亚、科、细蜉科、四节蜉科、短丝蜉科、晚蜉科、石蝇幼虫、纹石蛾科、蚋科 }\end{array}$ & 529 \\
\hline $\begin{array}{c}\text { 山仔水库 } \\
\text { (日溪人库处) }\end{array}$ & 顠体虫科、仙女虫科、扁卷螺科、瓶螺科、摇蚊亚科、四节蜉科、黾蝽科、长臂虾科 & 16 \\
\hline 山仔水库 & 颤蚓科、仙女虫科、瓶螺科、摇蚊亚科、长足摇蚊亚科 & 20 \\
\hline $\begin{array}{c}\text { 敖江干流 } \\
\text { (近塘板水库) }\end{array}$ & $\begin{array}{l}\text { 仙女虫科、椎实螺科、圆田螺科、瓶螺科、摇蚊亚科、长足摇蚊亚科、四节蜉科、长臂虾 } \\
\text { 科、溪蟹科、方蟹科 }\end{array}$ & 114 \\
\hline 潘渡溪 & $\begin{array}{l}\text { 涡虫纲、仙女虫科、扁蛭科、椎实螺科、圆田螺科、觽螺科、扁卷螺科、瓶螺科、蚬科、贻 } \\
\text { 贝科、蟌科、摇蚁亚科、直突摇蚊亚科、四节蜉科、蚋科、蠓科、匙指虾科、长臂虾科、方 } \\
\text { 蟹科、钩虾科 }\end{array}$ & 277 \\
\hline 下游浦口 & 带丝蚓科、瓶螺科、长足虹科、匙指虾科、沙蟹科、方蟹科 & 57 \\
\hline
\end{tabular}

3.2 .2 鱼类群落分析 鱼类位于水生生态食物链的顶端, 其状况是河流健康的重要反映, 能在一定范围内敏 感地反映水质和栖息地的退化情况 ${ }^{[20]}$. 鱼类对水质变化反应灵敏, 据欧洲内陆渔业咨询委员会建议, 鱼类能 长期忍受氨氮浓度的最大限度为 $0.25 \mathrm{mg} / \mathrm{L}$. 近年来, 敖江流域由于一系列人为活动 (电站水坝拦截、挖砂、 过度捕捞、水域污染等), 鱼类生境受到不同程度的破坏.

根据调查, 敖江流域河道鱼类主要有鲤鱼 (Cyprinus carpio)、鲫鱼 (Carassius auratus)、鲢鱼 (Hypophthalmichthys molitrix)、草鱼 (Ctenopharyngodon idellus)、半刺厚唇鱼(Acrossocheilus hemispinus)、马口鱼 (Opsariichthys uncirostris)、棒花鱼 (Abbottina fukiensis)、黄颡鱼 (Pelteobagrus fulvidraco)、胡子鲶 (Clarias fuscus) 和拟腹 吸鱾 (Pseudogastromyzon fasciatus) 等. 近年来由于石板业的发展, 河水受到污染和存在违法电捕现象, 中上游 河段鱼类越来越少. 敖江流域现场采集的鱼类标本与访查所得的鱼类, 经鉴定有 86 种, 隶属于 13 目 31 科 
73 属, 除了尼罗罗非鱼为外来人侵鱼种外, 其它基本为土著鱼种, 中国特有鱼种 12 种, 上、中、下游各科物种 组成差异不显著. 此外, 敖江流域大部分鱼类为广布种, 珍稀鱼类少, 在珍稀鱼类中, 花鳗鲡 (Anguilla marmorata) 为濒危物种 (EN), 属国家二级保护动物, 鲥鱼 (Macrura reevesi) 和香鱼 (Plecoglossus altivelis) 分别为濒 危物种和易危物种 $(\mathrm{VU})$, 属福建省级重点保护水生野生动物.

从鱼类区系特点分析, 敖江流域淡水鱼类的分布区系属于东洋区华南亚区的浙闽分区, 主要以中国江 河平原复合体和南方热带平原复合体占主导地位, 中印山区复合体和上第三纪鱼类区系复合体也占有一定 比例, 具有较明显的热带、亚热带区系特点.

3.2.3 水利工程建设对水生生境的影响 敖江流域水能丰富, 据调查敖江流域存在规模较大的水电站共 11 座, 大部分属引水式, 造成不同程度的脱水段, 影响河道水生生物的生境, 对河道径流调节起到很大作用, 同 时, 水库改变了底栖动物的生境多样性, 较为单一的水库生境取代了流域主流、支流、急流和浅滩等丰富多 样的生境. 流域梯级开发降低水的自净能力, 减缓流速, 使水的更换期延长、复氧能力降低, 给藻类生长提供 有利条件, 不利于底栖动物敏感物种的生存, 滋生大量耐缺氧和耐有机的颤蚓类、摇蚊类, 破坏水生态的平 衡. 此外, 水利工程的拦截水坝, 全都无过鱼通道, 对洄游性鱼类影响较大, 也分割了定居性鱼类的生境 ${ }^{[21]}$, 2013 年夏季敖江鱼类调研中, 在潘渡电站坝下水域中捕获香鱼和花鲇 (Lateolabrax japonicus), 这 2 种鱼类为 河口鱼类, 说明可从河口洄游至此, 但在潘渡电站坝上及以上流域均未发现这 2 种鱼, 可能与敖江流域上的 多级小水电建坝阻断洄游通道有关.

\section{3 水域生态系统健康评估}

3.3.1 评估指标解释和计算方法 根据流域生态健康评估指标体系分析方法, 敖江流域水域生态系统健康 评估指标解释和计算方法见表 6.

表 6 敖江流域水域生态系统健康评估指标解释和计算方法

Tab. 6 Explanation and computing method of health evaluation index of aquatic ecosystem in Aojiang Basin

\begin{tabular}{lll}
\hline 评估指标 & 指标解释 & 计算方法 \\
\hline 水质状况指数 & $\begin{array}{l}\text { 流域 III 类及以上等级水质监测断面数 } \\
\text { 占水质状况指数 }=\text { 流域全部监测断面数的比例 }\end{array}$ 部监测断面数
\end{tabular}

枯水期径流量占同 枯水期径流量占同期年均径流量比例 枯水期径流量占同期年均径流量比例 $=$ 枯水期径流量/枯 期年均径流量比例 反映流域 (调洪) 补枯的功能, 衡量河 水期同期年均径流量

流生态需水量的满足程度

河道连通性河道连通性是指自然河道的连通状况, 河道连通性 $=$ (闸坝、水电站等水利工程个数) $/ 100 \mathrm{~km}$ 利用每百千米河道的闸坝个数评估河 道的连通性

大型底栖动物多样 选取反映大型底栖动物多样性的多个 采用指标包括: 大型底栖动物分类单元数 $(S)$ 、大型底栖动 性综合指数 指标进行综合评估,表征大型底栖动物 物 EPT 科技分类单元比 (EPTr-F)、大型底栖动物 BMWP 指 的物种完整性状况 数 $(B M W P)$ 、大型底栖动物 Berger-Parker 指数 $(D)$. 首先进 行指标的标准化,然后计算四个指标的算术平均值

鱼类物种多样性综 选取反映鱼类物种多样性的多个指标 采用指标包括: 鱼类总分类单元数 $(S)$ 、鱼类香农一威纳多样 合指数 进行综合评估,表征鱼类的物种完整性 状况

性指数 $\left(H^{\prime}\right)$ 、鱼类 Berger-Parker 优势度指数 $(D)$.
指标的标准化, 然后计算 3 个指标的算术平均值

特有性或指示性物 反映河流特有性、指示性物种以及珍惜 根据水生物调查或问卷统计获取

种保持率 濒危物种的保护状况. 以历史水平数据 为基准,进行对比分析

水资源开发利用 反映流域水资源的开发利用程度,根据 水资源开发利用强度 = 区域工业、农业、生活等用水量/区 强度

区域工业、农业、生活、环境等用水量占 域水资源总量 $\times 100 \%$

评估区域的水资源总量比值进行评估

水生生境干扰指数 反映水域生境遭到人为挖砂、航运、旅 水生生境干扰指数 $=\sum_{i=1}^{n} H_{i} \cdot \omega_{i}$
游等活动破坏的影响状况

$H_{i}$ 表示第 $i$ 项指标健康分值, $\omega_{i}$ 表示第 $i$ 项指标权重,其中 $i$ 为 3 .

赋分为根据水域的生态压力内容, 实地调研获取

3.3.2 评估结果 根据流域生态健康评估指标计算方法, 计算得出敖江流域水域生态系统健康评估指标, 并 
对计算结果进行赋分 (表 7). 其中, 水质状况指数赋分时, 上游单元水质达标率 $100 \%$, 但考虑霍口断面、双 渡溪断面的浊度达标率分别为 $88.08 \%$ 和 $88.17 \%$, 水质评定为优秀, 赋分 94 ; 下游单元水质达标率 $100 \%$, 考虑花园溪和兰水溪 2 条支流浊度达标率均较低, 水质评价定为一般, 赋分 50 ; 河道连通性方面, 虽然按照 丘陵分级标准, 上游、中游和下游评估水系结果属于良好, 但考虑到实际调研中敖江流域小水电站分布较 多,故最终评估结果降 1 级为一般,分别赋分 $58 、 58 、 60$.

表 7 敖江流域水域生态系统健康评估各指标值及赋分情况

Tab. 7 Values and scores of health evaluation index of aquatic ecosystem in Aojiang Basin

\begin{tabular}{|c|c|c|c|c|c|c|c|c|}
\hline \multirow{2}{*}{ 指标类型 } & \multirow{2}{*}{\multicolumn{2}{|c|}{ 评估指标 }} & \multicolumn{2}{|c|}{ 上游 } & \multicolumn{2}{|l|}{ 中游 } & \multicolumn{2}{|c|}{ 下游 } \\
\hline & & & 指标值 & 赋分 & 指标值 & 赋分 & 指标值 & 赋分 \\
\hline \multirow[t]{3}{*}{ 生态结构 } & \multirow{3}{*}{\multicolumn{2}{|c|}{$\begin{array}{l}\text { 水质状况指数 } \\
\text { 枯水期径流量占同期年均径流量比例 } \\
\text { 河道连通性 }\end{array}$}} & $100 \%$ & 94 & $25 \%$ & 25 & $100 \%$ & 50 \\
\hline & & & $13.0 \%$ & 100 & $13.0 \%$ & 100 & $13.0 \%$ & 100 \\
\hline & & & $6 / 100$ & 58 & $6 / 100$ & 58 & $8 / 100$ & 50 \\
\hline \multirow[t]{3}{*}{ 水生生物 } & \multicolumn{2}{|c|}{ 大型底栖动物多样性综合指数 } & 0.32 & 32 & 0.45 & 45 & 0.37 & 37 \\
\hline & \multicolumn{2}{|c|}{ 鱼类物种多样性综合指数 } & 0.23 & 23 & 0.66 & 66 & 0.9 & 90 \\
\hline & \multicolumn{2}{|c|}{ 特有性或指示性物种保持率 } & 无变化 & 50 & 无变化 & 50 & 无变化 & 50 \\
\hline \multirow[t]{5}{*}{ 生态压力 } & \multicolumn{2}{|c|}{ 水资源开发利用强度 } & $24.76 \%$ & 74 & $25.13 \%$ & 74 & $28.44 \%$ & 70 \\
\hline & 水生 & 挖沙 & 极少 & 70 & 部分区域可见 & 50 & 常见 & 30 \\
\hline & 生境 & 航运交通或涉水旅游 & 无 & 90 & 常见 & 20 & 常见 & 20 \\
\hline & 干扰 & 网箱养殖 & - & - & 无 & 100 & - & - \\
\hline & 指数 & 外来物种种类、数量、比例 & 无变化 & 50 & 无变化 & 50 & 无变化 & 50 \\
\hline
\end{tabular}

水域健康指数值计算公式为: $I_{\mathrm{W}}=\sum_{i=1}^{n} W_{i} \cdot X_{i}$, 其中 $I_{\mathrm{W}}$ 为水域生态系统健康指数值, $W_{i}$ 为水域生态系统 健康评估指标权重, $X_{i}$ 为水域生态系统健康评估指标值. 通过 $I_{\mathrm{W}}$ 大小, 将流域陆域生态系统健康等级划分 为: 优秀 $\left(I_{\mathrm{W}} \geqslant 80\right)$ 、良好 $\left(60 \leqslant I_{\mathrm{W}}<80\right)$ 、一般 $\left(40 \leqslant I_{\mathrm{W}}<60\right)$ 、较差 $\left(20 \leqslant I_{\mathrm{W}}<40\right)$ 、差 $\left(I_{\mathrm{W}}<20\right)$.

根据表 3 中的水域健康评估指标权重和表 7 中的水域健康评估指标赋值, 对敖江流域水域生态系统健 康状态进行评估, 结果为: 上游水系分值为 65.8 , 水域生态系统健康良好; 中游水系分值为 60.8 , 水域生态系 统健康良好;水域水系分值为 59.2 , 陆域生态系统健康一般.

从各项指标分值来看, 上游水系水域生态健康为良好, 其中枯水期径流比例、水质状况、航运交通或涉 水旅游等方面评估结果均为优秀, 水资源开发利用强度、挖沙情况评估结果为良好, 河道连通性、特有性或 指示性物种保持情况、外来物种种类/数量/比例等方面评估结果为一般, 但鱼类、大型底栖动物多样性等方 面评估结果为较差; 中游水系水域生态健康为良好, 其中枯水期径流比例和网箱养殖方面评估结果为优秀, 水资源开发利用强度和鱼类物种多样性方面评估结果为良好, 河道连通性、特有性或指示性物种保持情况、 挖沙情况、外来物种种类/数量/比例、大型底栖动物多样性等评估结果为一般, 但水质状况、航运交通或涉 水旅游评估结果为较差; 下游水系水域生态健康为一般, 枯水期径流比例和鱼类物种多样性方面评估结果 为优秀, 水资源开发利用强度方面评估结果为良好, 水质状况、河道连通性、特有性或指示性物种保持情况、 外来物种种类/数量/比例等方面评估结果为一般, 大型底栖动物多样性、挖沙情况、航运交通或涉水旅游等 方面评估结果较差.

\section{4 结论}

敖江流域水质总体较好, 水质呈逐步改善趋势, 浊度达标率有所提高, 但是山仔水库 TN 、TP 浓度长期超 标, 水体存在富营养化和藻类暴发生态环境问题. 流域底栖动物种类呈现支流多于干流, 河流多于水库的规 律; 鱼类种类上、中、下游各科物种组成差异不显著, 具有较明显的热带、亚热带区系特点. 流域梯级电站开 发强度大, 对水生态平衡产生一定程度的破坏, 且对洄游性鱼类影响较大. 敖江流域水域生态系统健康评估 表明流域上游、中游水系水域生态健康良好, 下游水系水域生态健康一般. 


\section{5 参考文献}

[1 ] 王文杰, 张 哲, 王 维等. 流域生态健康评价框架及其评价方法体系研究一一框架和指标体系. 环境工程技术学 报,2012,2(4):272-277.

[2 ] 龙 笛,张思聪,訤朝宇. 流域生态系统健康评价研究. 资源科学, 2006,28(4):38-43.

[ 3 ] Hong B, Limburg KE, Erichson JD et al. Connecting the ecological-economic dots in human-dominated watersheds: models to link socio-economic activities on the landscape to stream ecosystem health. Landscape and Urban Planning, 2009, $91(2)$ : 78-87.

[ 4 ] Ayensu. International ecosystem assessment. Science, 2000, 286(5440) : 6851.

[ 5 ] Volstad JH, Neerchal NK, Roth NE et al. Combining biological indicators of watershed condition from multiple sampling program's a case study from Maryland, USA. Ecological Indicators, 2003, 3(1) : 213-251.

[ 6 ] Beck MB. Vulnerability of water quality in intensively developing urban watersheds. Environment Modelling \& Software, $2005,20(4): 381-400$.

[ 7 ] Schultz MT. A critique of EPA's index of watershed indicators. Journal of Environmental Management, 2001, 62 (4) : 429-442.

[ 8 ] Wang X. Integrating water quality management and land-use planning in a watershed context. Journal of Environmental Management, 2001, 62(4) : 25-36.

[ 9 ] 刘炎序,彭 建,汪 安等.生态系统健康研究新进展与趋向. 生态学报,2015,35(18):1-16.

[10］罗跃初,周忠轩,孙 轶等. 流域生态系统健康评价方法.生态学报,2003,23(8):1606-1614.

［11］李春晖,崔 嵬,庞爱萍等. 流域生态健康评价理论与方法研究进展. 地理科学进展, 2008, (1):9-17.

[12] 翁笑艳. 山仔水库叶绿 a 与环境因子的相关分析及富营养化评价. 干旱环境监测,2002,20(2): 74-78.

[13] 李小梅, 吴春山, 庄一廷等. 石板材加工行业的水环境污染特征研究. 福建师范大学学报: 自然科学版, 2009, 22 (4) :68-79.

[14] 饶清华,邱 宇,王菲风. 福建省山仔水库生态安全评价. 水土保持研究,2011,18(5):222-225.

[15] 胡 军. 敖江流域典型污染行业生态补偿标准初探——古田县石材为例 [ 学位论文]. 福州: 福建师范大学, $2012: 15$.

[16] 成庆泰,郑葆珊. 中国鱼类系统检索 (上、下). 北京:科学出版社,1987.

[17］环境保护部自然生态保护司. 流域生态健康评估技术指南(试行),2013.

[18］翁笑艳,杨 芳,林志鹏. 福建省山仔水库水质现状及演变趋势分析. 环境科学与管理, 2011,36(8):114-121.

[19] 张玉珍, 苏玉萍, 陈能汪等. 福州市山仔一塘坂水库富营养化和藻类水华防治对策及应急处置方法研究. 福建省环 境科学研究院,2013.

[20] 张红叶,蔡庆华, 唐 涛等. 洱海流域湖泊生态系统健康综合评价与比较. 中国环境科学, 2012,32(4):715-720.

[21] 刘恩生. 鱼类和水环境间相互关系的研究回顾与设想. 水产学报,2007,31(3):391-399. 